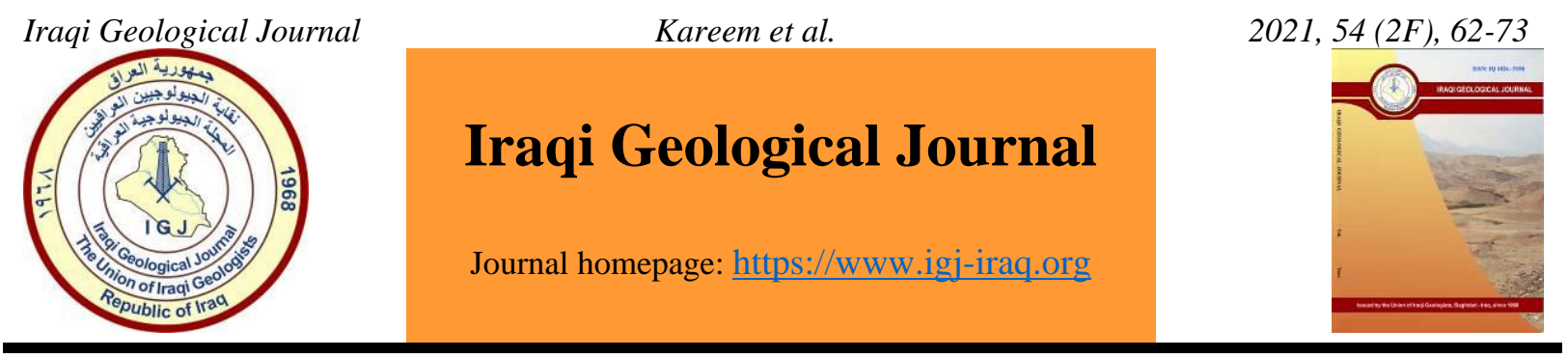

\title{
Structural Study of Faihaa Oil Field in Basra South of Iraq
}

\author{
Hiba A. Kareem ${ }^{1} *$, Manal Sh. Al-Kubaisi ${ }^{1}$ and Ghazi Hasan Alshar'a ${ }^{2}$ \\ 1 Department of Geology, College of Science, University of Baghdad, Baghdad, Iraq \\ 2 Oil Exploration Company, Ministry of Oil, Baghdad, Iraq \\ * Correspondence: hibaaldulimy93@gmail.com
}

Received: 19 September 2021; Accepted: 19 October 2021; Published: 31 December 2021

\begin{abstract}
This study used structural contour maps to carry out the geometrical analysis for Faihaa structure in Basra southern Iraq. The study used row data of well logs and structural maps while Softwares were Didger 4, Stereonet v.11 and Petrel 2017 Faihaa Oil Field is located at an eastern part of the Mesopotamian Zone within the Zubair Subzone, characterized by subsurface geological structures covered by Quaternary sediments. These structures are oriented in the NW-SE direction in the eastern part of the band and the N-S direction in the southern region, and some in the direction NE-SW. The Faihaa Oil Field shows that is an Anticline structure. The average dip value of an axial surface is $89.7^{\circ}$ while the plunge of hinge line between 4-4.2 in North-West direction referred to that Faihaa Structure is upright and gentle fold. Based on the Thickness ratio and axial angle, the Faihaa Structure is thickened Fold. The eastern limb of the fold is longer than the western limb, so Faihaa Oil Field is an asymmetrical structure. The difference in dimensions $(5<$ Length / Width $<2)$ confirmed the brachy fold of the Faihaa structure.
\end{abstract}

Keywords: Structural study; Faihaa Oil Field; Mishrif Formation; South of Iraq

\section{Introduction}

Faihaa Oil Field is located at the eastern part of the Mesopotamian Zone within Zubair Subzone, characterized by subsurface geological structures covered by Quaternary sediments. These structures are oriented in the NW-SE direction in the eastern part of the band and the N-S direction in the southern region, and some in the direction NE-SW (Jassim and Goff, 2006). This field consist of six oil wells (FH-1, FH-2, FH-3, FH-4, FH-5 and FH-6).

The Mishrif Formation is one of the Iraqi major oil reserves in southern Iraq. This formation consists of limestone deposited during a Lower Cretaceous period as part of the main series of transgression depositions. It is the most important carbonate reservoir in south east Iraq and contain oil at 32 structures. The largest accumulation is in the West Qurna, Zubair, Rumaila North, Rumaila South, Majnooon, and Halfaiya Fields, positioned on large-scale north-south trending anticline. At least 15 other commercial oil accumulation in Mishrif Formation have been discovered in south east Iraq: Buzurgan, Dujaila, Jabel Fauqi, Gharraf, Hawaiza, Abu Ghirab, Ahdab, Amara, etc. (Aqrawi et al., 2010). This study aims to analyze the structure of the Faihaa Field using well logs.

In the previous studies of Faihaa Oil Field, Altimimi (2019) studied Advanced Reservoir Characterization tools and Modeling for carbonate reservoir Yamama Formation in Faihaa Oil Field in

DOI: $\underline{10.46717 / \text { igj.54.2F.6ms-2021-12-23 }}$ 
southern Iraq. He said advance log Fullbore Formation MicroImager (FMI) of Faihaa-1gaven more details about determined porous layers from non-porous layers and types of porosity distribution according to new Schlumberger classification of image logs, types of the fractures (open fractures and closed fractures); most of the fractures were horizontal Alhassani (2020) studied biostratigraphy, and depositional environment of the Yamama Formation in Faihaa Oil Field, Southern Iraq, and she said that Faihaa well affected by six mainly diagenetic processes: dissolution processes that formed many types of porosities vuggy and melodic porosities, the most effective are cementations which formed syntaxial rim cement is very common in the Yamama Formation. Where interparticle pores are filled by cement and granular (blocky) cement, Other diagenetic processes such as neomorphism, micritization, dolomitization, and compaction are less effective.

\section{Location of the Study Area}

Faihaa Oil Field is located close to Iraqi-Iranian borders (Fig. 1), about 50km to the north of Basra city center. The area of this Field is about $900 \mathrm{~km}^{2}$. It is bordered by the north Majnoon Oil Field, the south Sindibad Field, the west Nahr Umr Field, and the east Husynia Iranian Field. It covers an area of $(2866 \mathrm{Km})$ which is a convex fold.

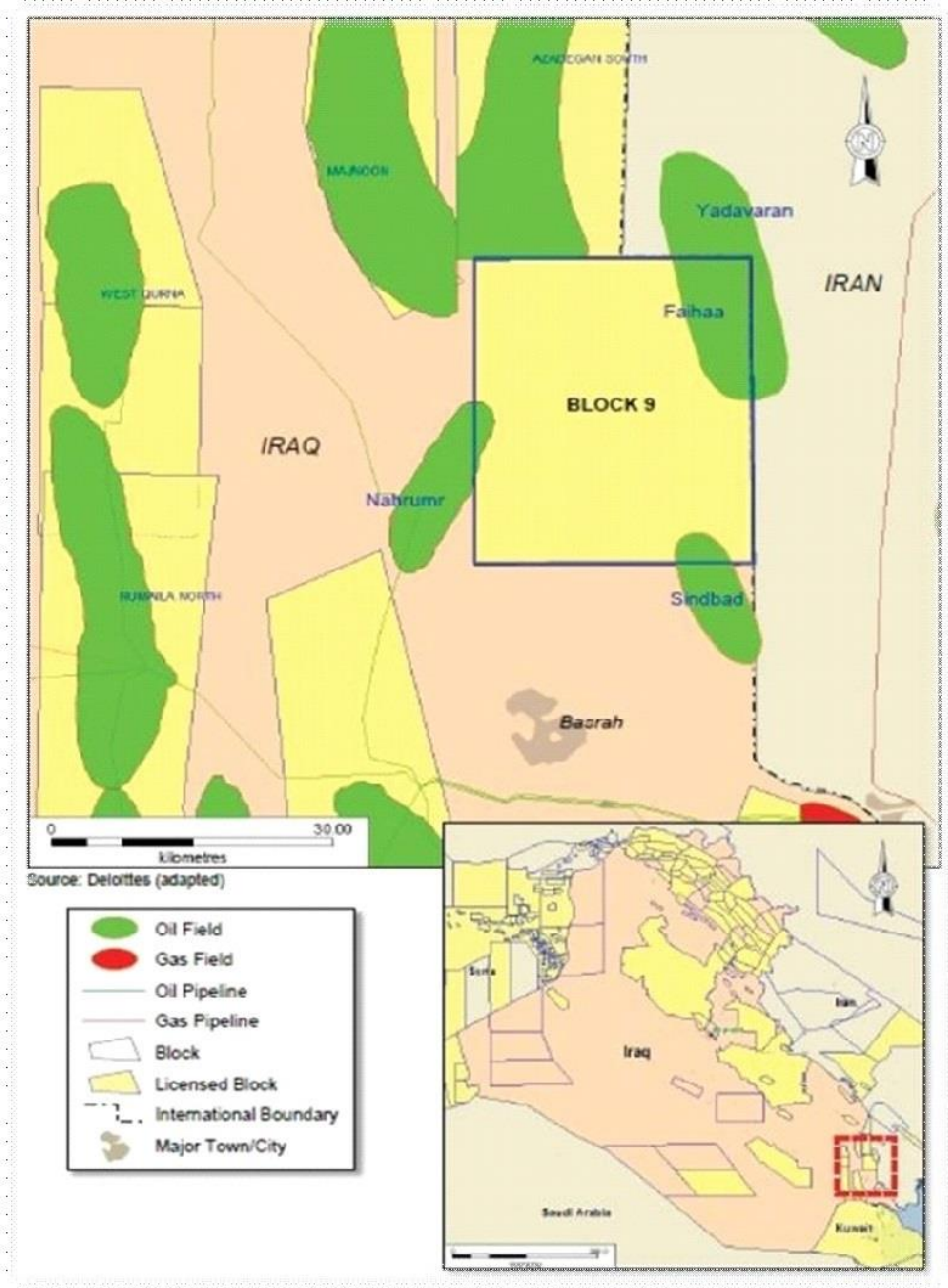

Fig.1. Location map of the study area (Faihaa Oil Field) ( S.O.C, 2016) 


\section{Materials and Methods}

To reach the study's aims, many approaches and software will be used. Petrel, Didger 4, Stereonet v.11 Software will be utilized to study the structural setting of the Faihaa Oil Field by using the inversion methods and seismic survey (Figs. 2 and 3).

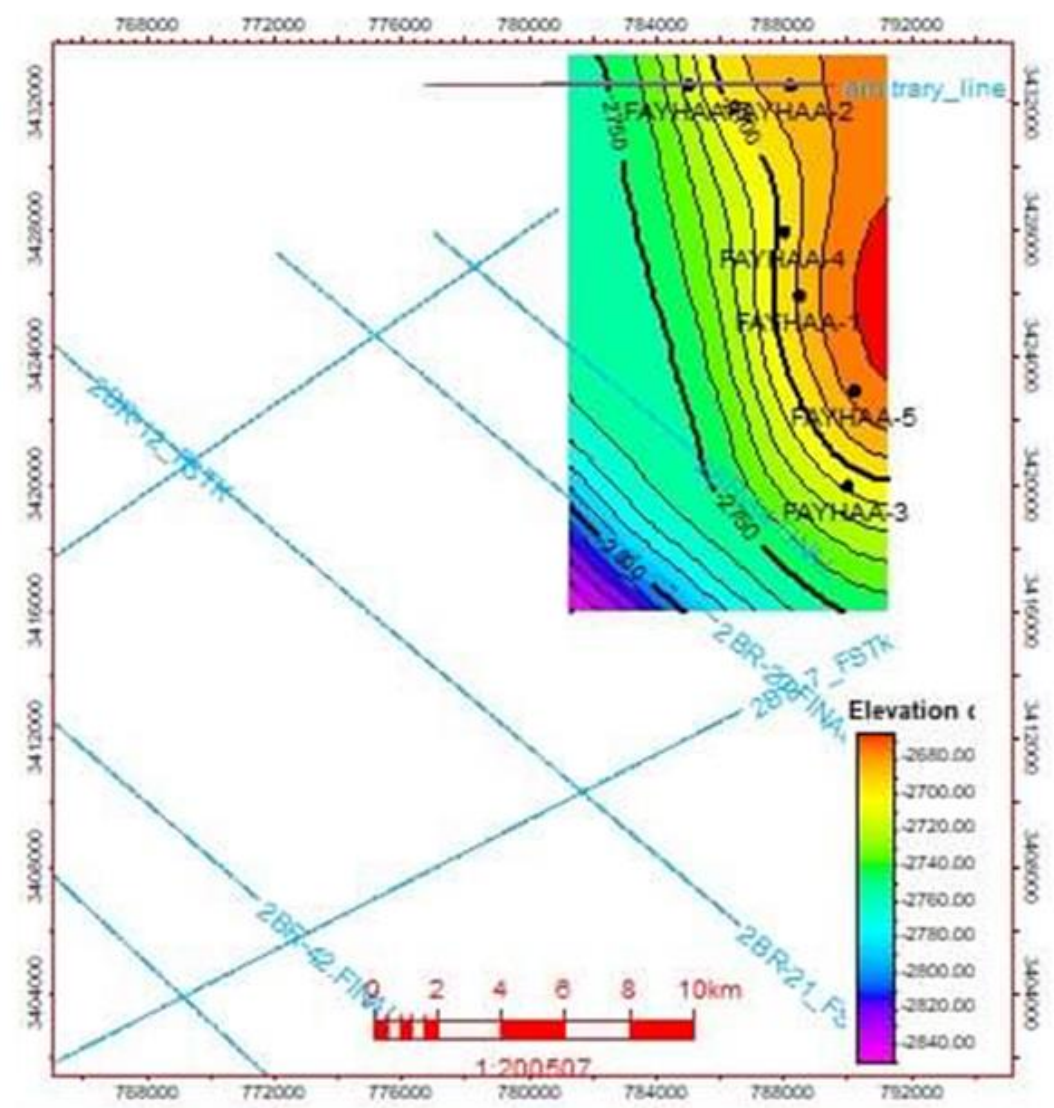

Fig.2. Structural contour map on top of the Mishrif Formation in Faihaa Oil Field (O.E.C)

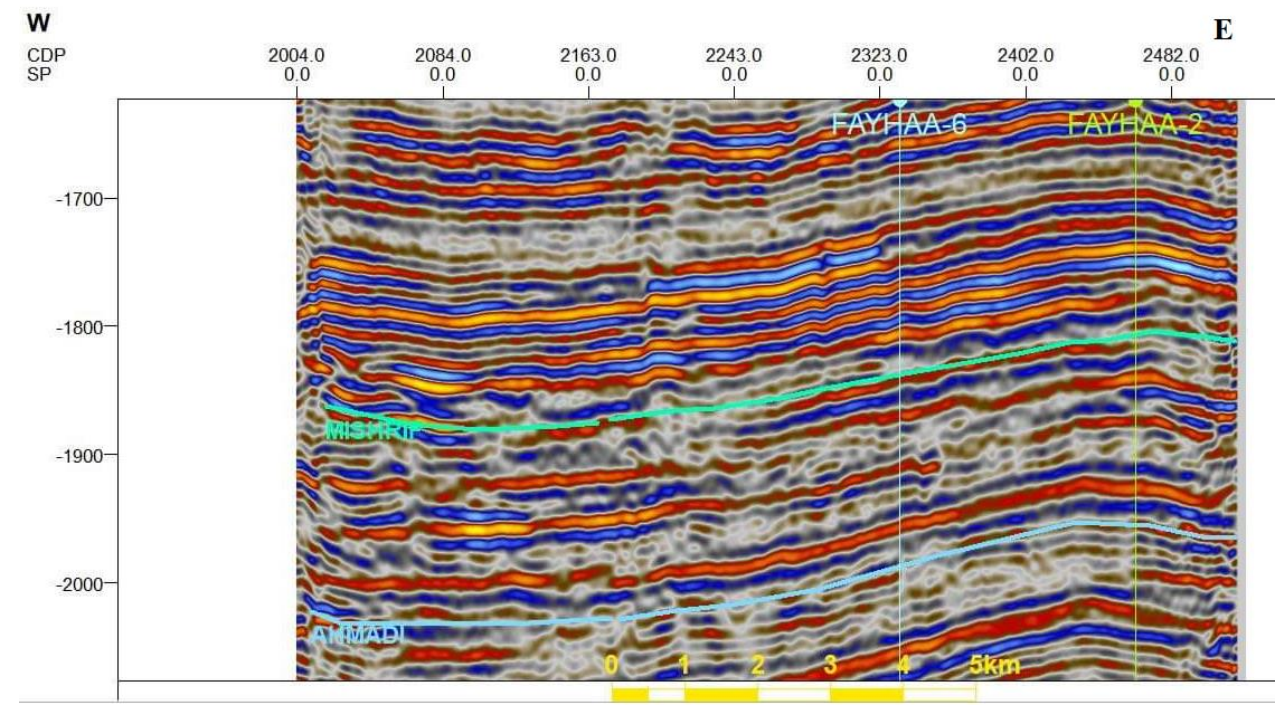

Fig.3. Seismic section (2BR19) of Faihaa Oil Field (O.E.C) 


\section{Classification of the Folds}

Folds display a variety of geometric shapes. Any structural study on folds thus requires identification or recognition of some specific geometric attributes or parameters which not only help in comparing the various fold types but also in classifying the folds in a systematic way (Fig. 4).

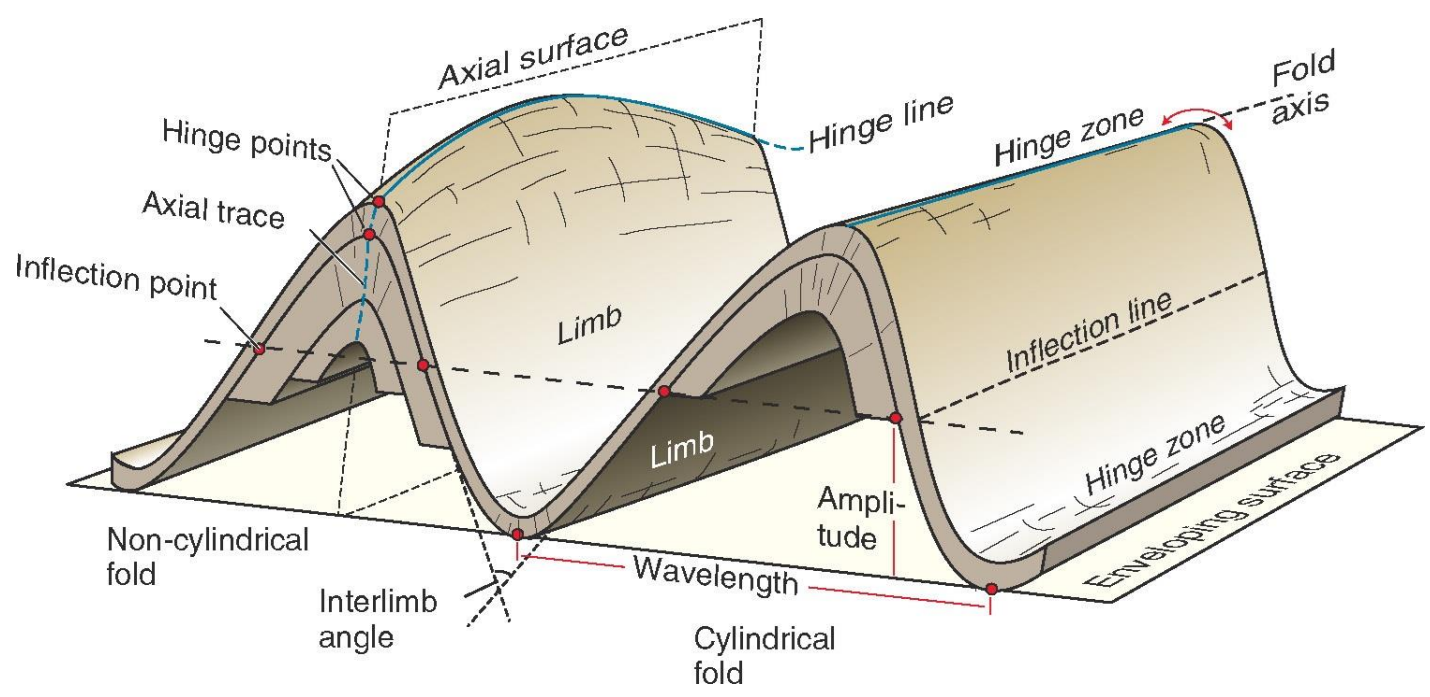

Fig.4. The geometric parameters of a fold (Fossen, 2015)

For a geometric analysis to produce the desired results, we need an integrated structural photo of the fold, since the current structural image lacks the presence of the Eastern Limb of the structure, which is located within the Iranian borders. Therefore, it was necessary to use the study (Block 9) carried out by Kuwait Energy Company to benefit the Basra Oil Company. The structural contour maps for Mishrif, Rumaila and Ahmadi were scanned (Figs. 5, 6 and 7) respectively, a simple geological model was made (Fig. 8), and two cross-sections were extracted (Figs. 9 and 10).

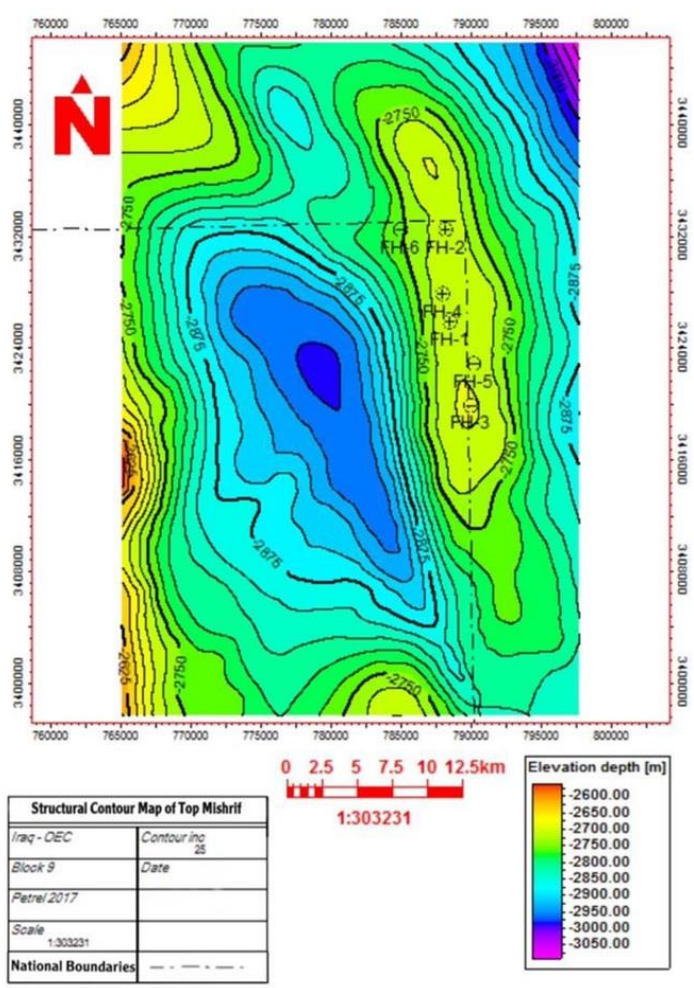

Fig.5. Structural contour map of top Mishrif Formation in Faihaa Oil Field (O.E.C) 


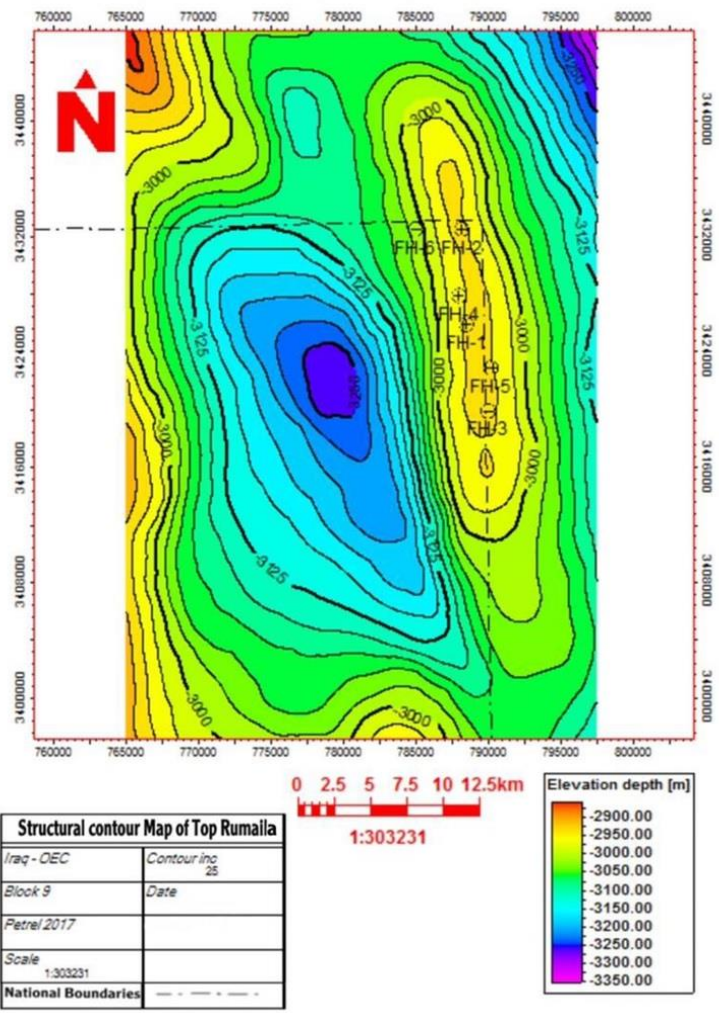

Fig.6. Structural contour map of top Rumaila Formation in Faihaa Oil Field (O.E.C)

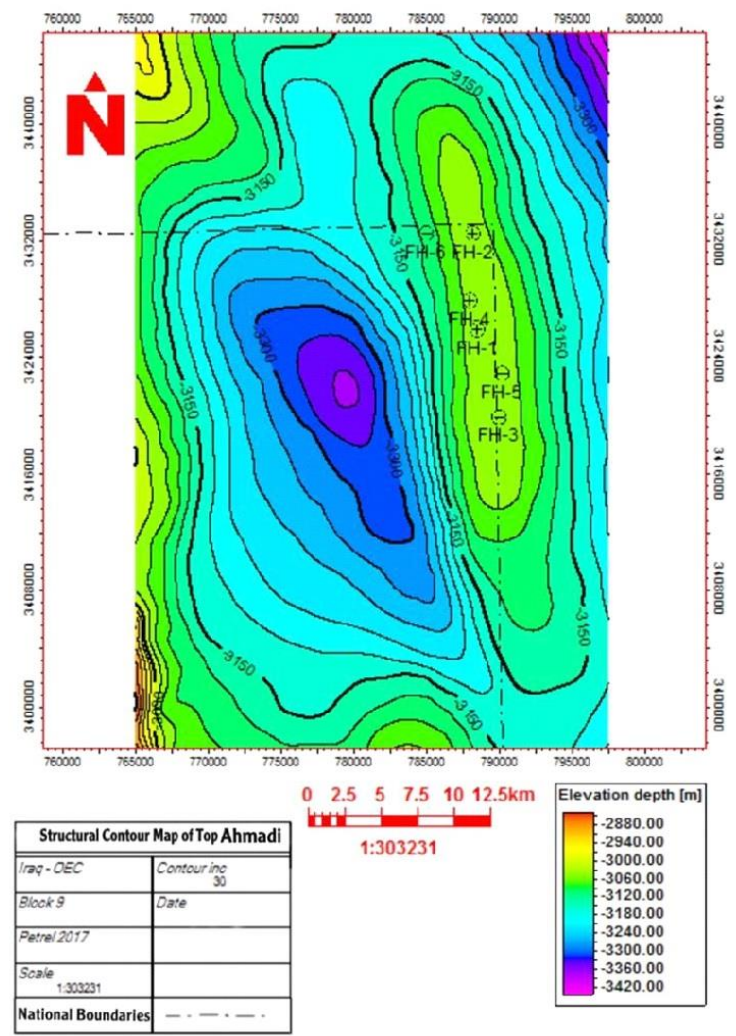

Fig.7. Structural contour map of top Ahmadi Formation in Faihaa Oil Field (O.E.C) 


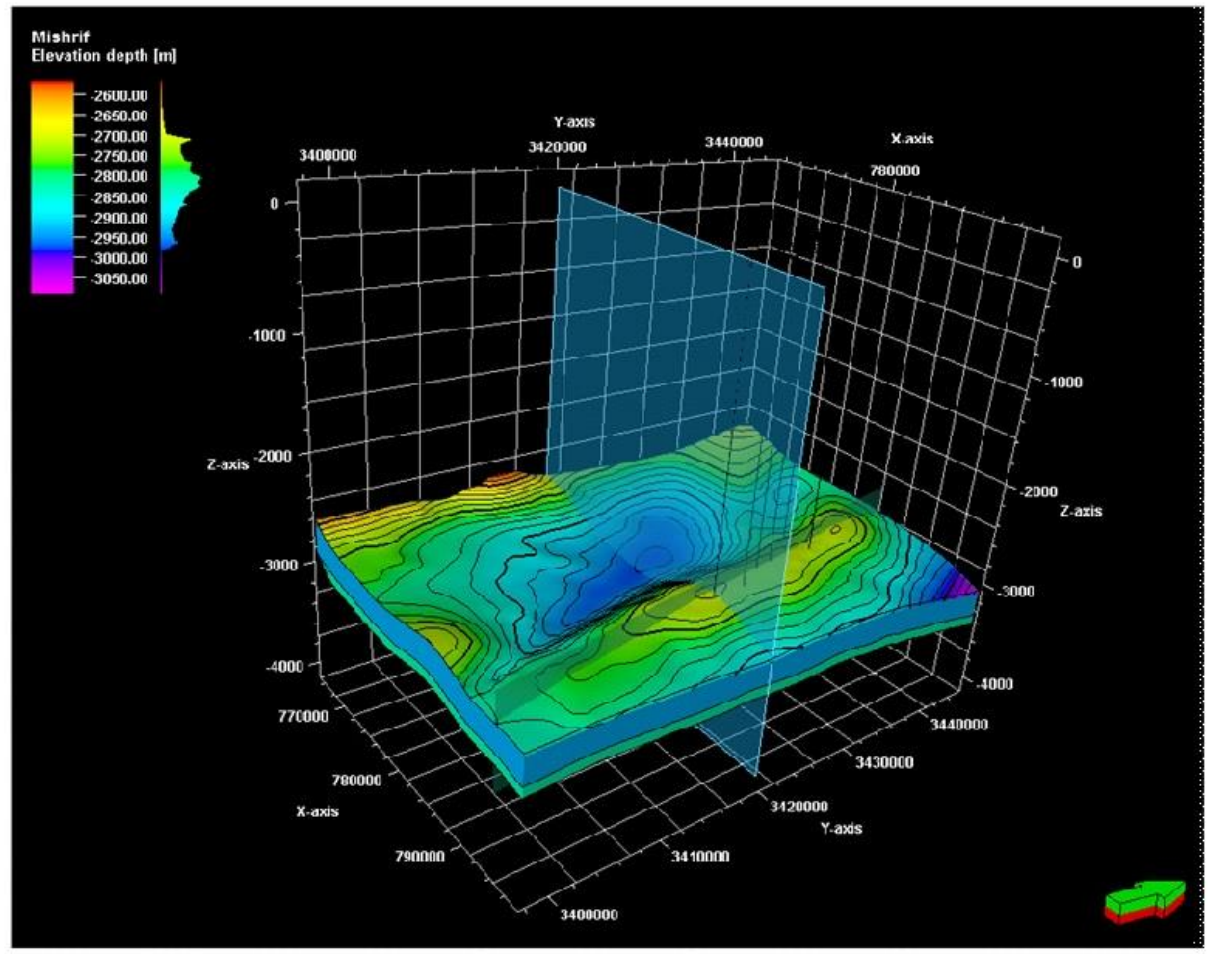

Fig.8. Simple grid model of Faihaa Oil Field (O.E.C)

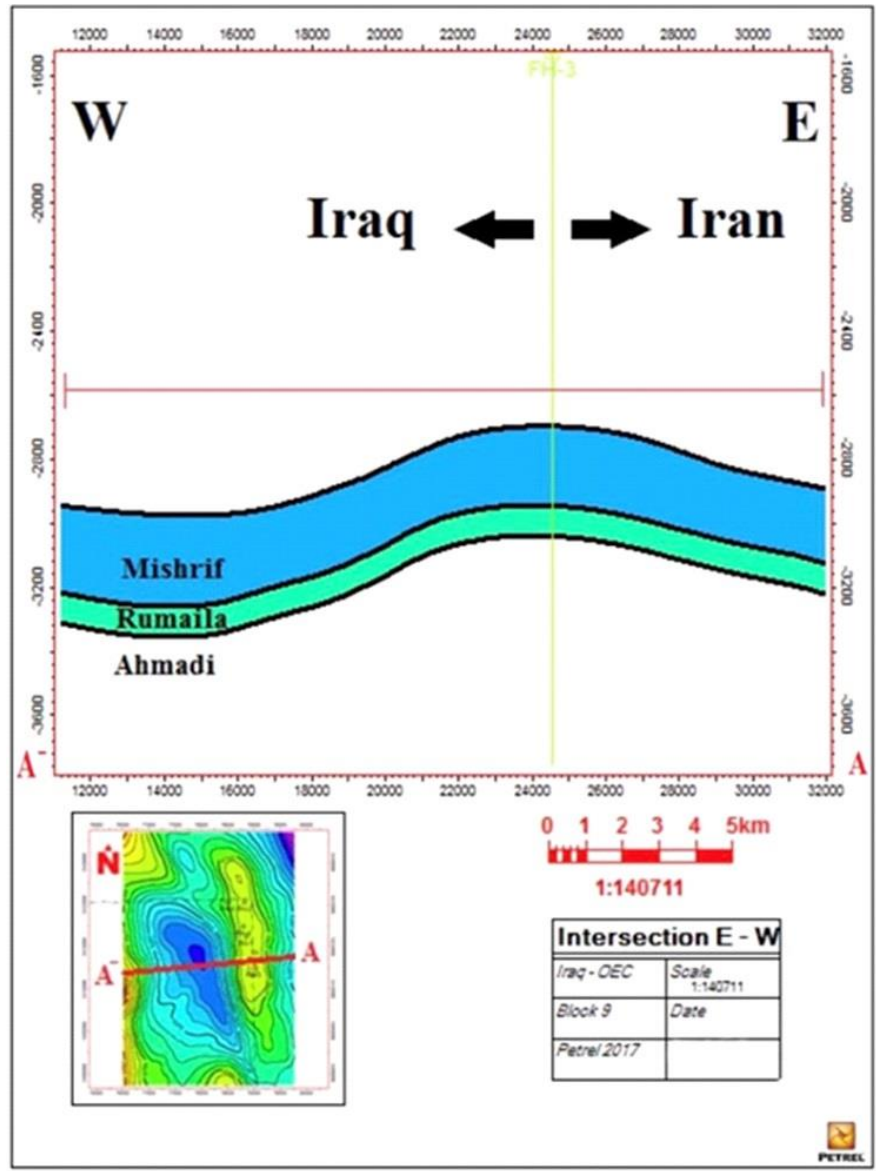

Fig.9. Cross-section (A - $\mathrm{A}^{-}$) of Faihaa Oil Field in the Mishrif Formation (O.E.C) 


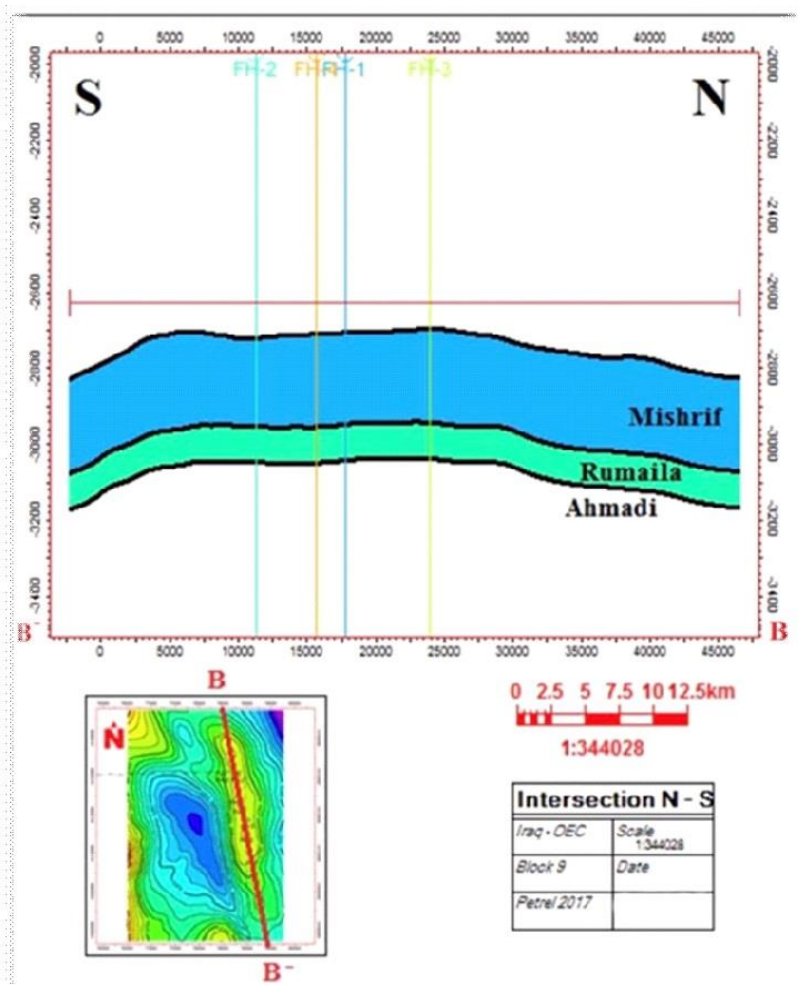

Fig.10. Cross-section (B - $\mathrm{B}^{-}$) of Faihaa Oil Field in Mishrif Formation,(O.E.C).

This study be categorized Faihaa Structure (The geometrical Analysis) based on the fold essential parameters, as following:

\section{Geometric Analysis}

1 - Fold facing

2 - Fold attitudes

- The symmetry of fold

- The plunge of hinge line

- Dip of axial surface

3 - Fold shape in profile plane

- Axial angle and thickness ratio

- Interlimb angle

4 - Fold dimensions

\subsection{Fold Facing}

The facing of a fold system refers to the geographic direction of younging (shown with an arrow) of the folds is separating upward and downward-Facing folds (Van Der Pluijm and Marshak, 2004). Antiforms are folded, which close upwards, where the limbs dip away from the hinge, while synforms are folds, which close downward, neutral folds fold, which close sideways, where the bedding gets younger upwards (Park, 1997). The cross-sections of the Faihaa Structure provide an anticline structure, perpendicular to the fold axis and parallel to the fold axis (Figs. 9 and 10).

\section{2. Fold Shape in Profile Plane}

A fold profile plane is defined as a plane taken perpendicular to a hinge line (Van Der Pluijm and Marshak, 2004). It involves specification of: 


\subsubsection{The interlimb angle}

Interlimb angle. In profile, the smaller angle made by the limbs of a fold, it is a measure of the tightness of the fold. It is the angle subtended by the tangents at two adjacent inflection points, which may reflect the intensity of compression (Fleuty, 1964). As shown in Table 1, the dip and dip direction values were calculated from three structural contour maps for the three formations of Faihaa Structure (Figs. 6, 7and 8).

Table 1. Calculation of dip and dip direction and plunge of the hinge line from the structure contour maps of Faihaa structure

\begin{tabular}{lcclc}
\hline $\begin{array}{l}\text { Formation } \\
\text { Name }\end{array}$ & \multicolumn{2}{c}{$\begin{array}{c}\text { Dip Direction } \\
\text { \& Dip amount }\end{array}$} & \multicolumn{2}{c}{ The plunge of the Hinge Line } \\
\hline & $\begin{array}{c}\text { South } \\
\text { western Limb }\end{array}$ & $\begin{array}{c}\text { North } \\
\text { eastern Limb }\end{array}$ & North West Plunge & $\begin{array}{c}\text { South } \\
\text { Plunge }\end{array}$ \\
& $240 / 8.2$ & $60 / 7.5^{\circ}$ & Plunge=0.1-Bearing=329 & $-4.2^{\circ}$ \\
Mishrif & $240 / 6.1$ & $58 / 6.5^{\circ}$ & Plunge $=0.1-$-Bearing=329 & $-2.9^{\circ}$ \\
Rumaila & $250 / 5.3$ & $68 / 5.6^{\circ}$ & Plunge= $0-$ - Bearing=339 & $-2^{\circ}$ \\
Ahmadi & & & & \\
\hline
\end{tabular}

The data that obtained from the calculation of dip and dip direction from the structure contour maps by taking the average values of dip and with use of the Stereonet Software (Figs. 11, 12 and 13) and the result in Table 2.

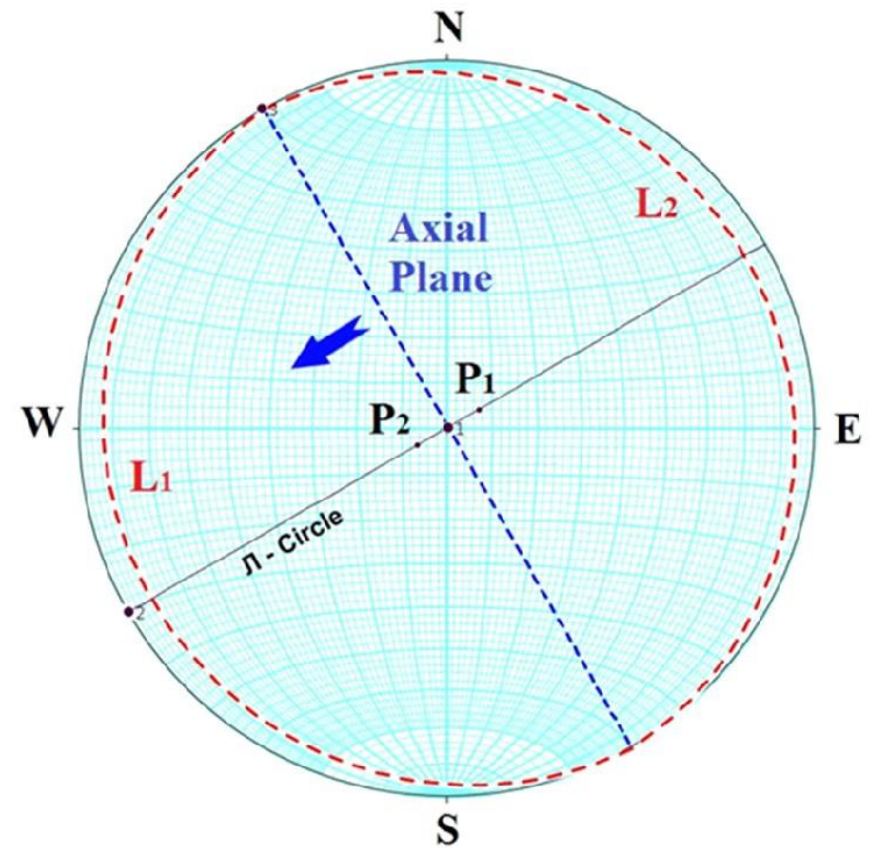

\begin{tabular}{|c|c|}
\hline \multicolumn{2}{|c|}{ Mishrif Formation } \\
\hline \multicolumn{2}{|c|}{$\begin{array}{l}\text {... Bisector \& Intersection of Two Planes } \\
\text { Planes dataset Untitled Planes }\end{array}$} \\
\hline Plane 1: Strike = & 330, dip $=7.5$ \\
\hline Plane 2: Strike = & 150, dip $=8.2$ \\
\hline Line of Intersection = & $330.0,00.0$ \\
\hline Angle between planes = & 164.3 \\
\hline Acute bisector. Strike $=$ & 150.0. Dip $=\infty 0.3$ \\
\hline Obtuse bisector. Strike = & 330.0. Dip $=89.7$ \\
\hline
\end{tabular}

Fig.11. Stereographic projection shows the attitude of Faihaa Structure on the Mishrif Formation 


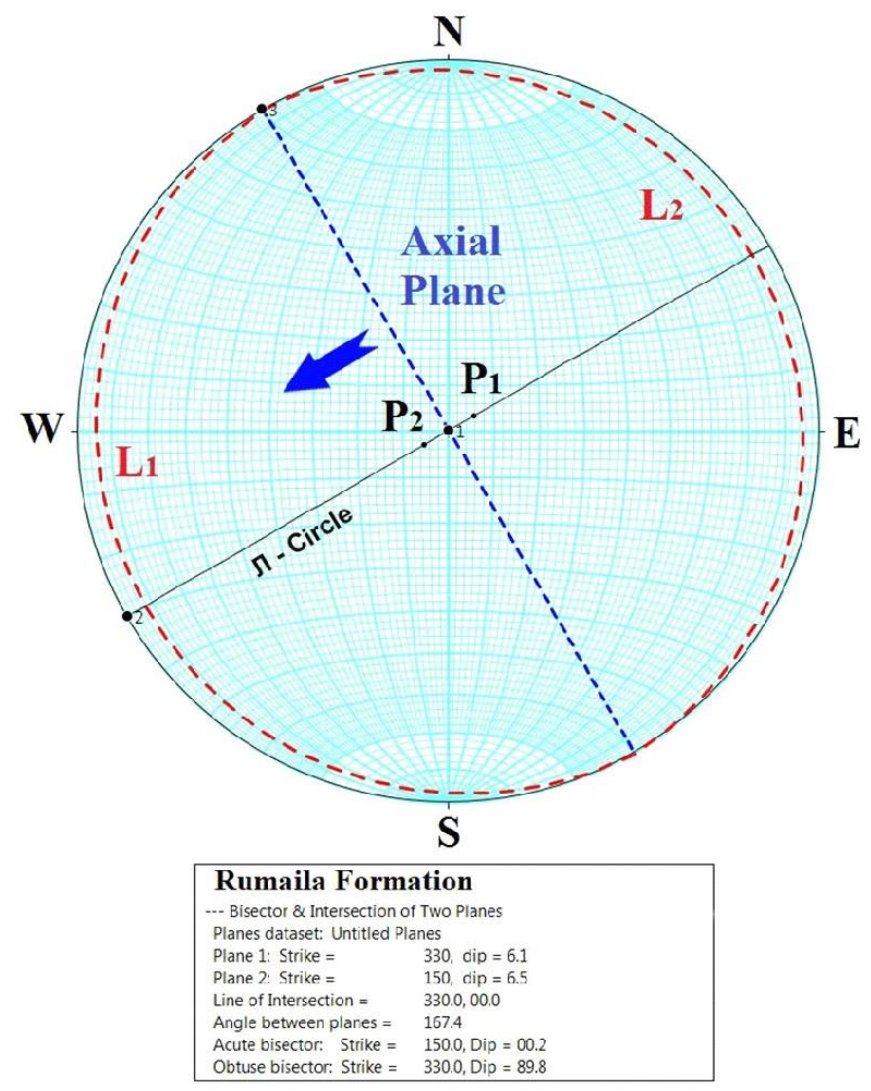

Fig.12. Stereographic projection shows the attitude of Faihaa Structure on the Rumaila Formation

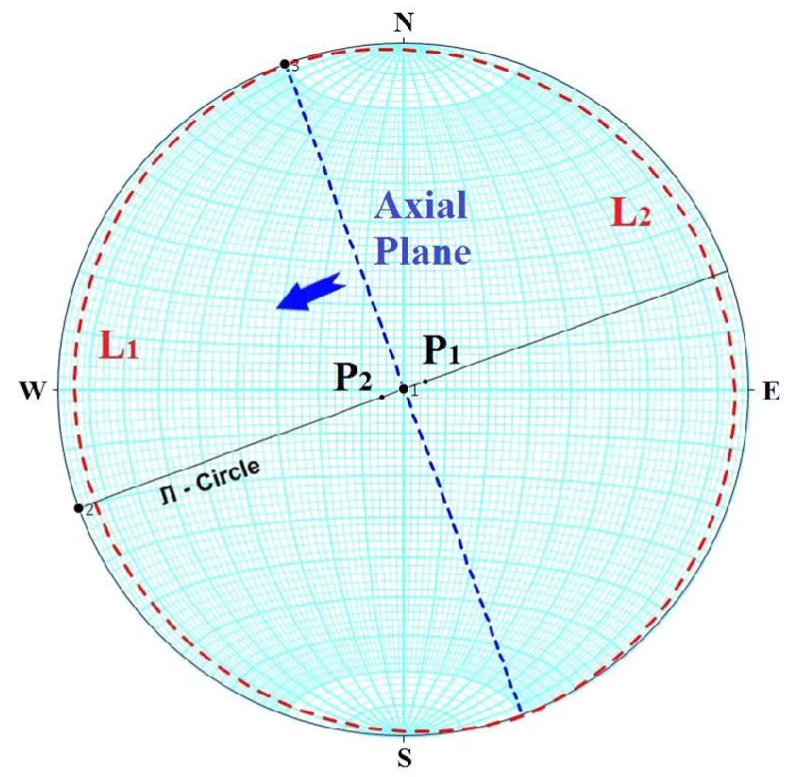

$$
\begin{aligned}
& \text { Ahmadi Formation } \\
& \text {-- Bisector \& Intersection of Two Planes } \\
& \text { Planes dataset: Untitled Planes } \\
& \begin{array}{ll}
\text { Plane 1: } \text { Strike }= & 340, \text { dip }=5.3 \\
\text { Plane 2: Strike }= & 160, \text { dip }=5.6
\end{array} \\
& \begin{array}{ll}
\text { Plane 2: Strike }= & 160, \text { dip }= \\
\text { Line of Intersection }= & 340.0,00.0
\end{array} \\
& \text { Angle between planes }=169.1 \\
& \text { Cbtuse bisector: Strike }=340.0 \text {. Dip }=00.1
\end{aligned}
$$

Fig.13. Stereographic projection shows the attitude of Faihaa Structure on the Ahmadi Formation 
Table 2.The attitude of Axial surface and the amount of interline angle using Stereonet Software

\begin{tabular}{lcc}
\hline Formation & $\begin{array}{c}\text { Strike and Dip amount of the } \\
\text { axial surface }\end{array}$ & The Interlimb Angle \\
\hline Mishrif & $330 / 89.7^{\circ}$ & $164.3^{\circ}$ \\
Rumaila & $330 / 89.8^{\circ}$ & $167.4^{\circ}$ \\
Ahmadi & $340 / 89.9^{\circ}$ & $169.1^{\circ}$ \\
\hline
\end{tabular}

According to the values in Table 2 and by comparing it with Fluety (1964), the fold is gentle

\section{2. 2. Axial angle and thickness ratio}

A thickness ratio $(\mathrm{R})$ is a ratio existing between a thickness of a limb and the thickness of the hinge. Axial Angle $(\alpha)$ is an angle for a given (inner or outer) trace or arc of the fold as across at an apex (hinge). An acute angle subtended by the inner and outer arcs at the apex is an inner axial angle $\left(\alpha_{\mathrm{i}}\right)$ and an outer axial angle $\left(\alpha_{0}\right)$ respectively (Fig. 14) (Bhattacharya, 2005).

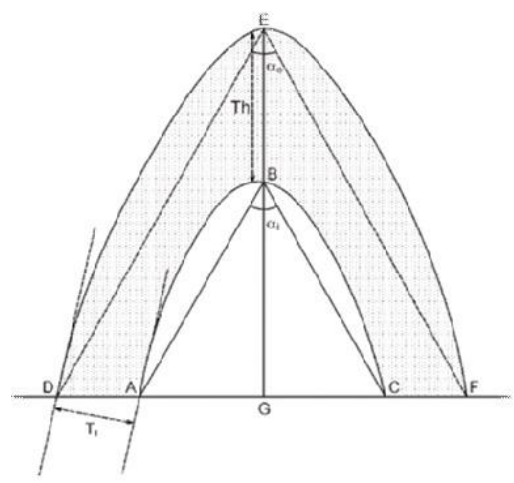

Fig.14. Fold section and parameters expressing the geometrical characteristics of a fold. DF = baseline; $\mathrm{GE}=$ axial plane; $\alpha_{\mathrm{i}}=$ axial angle for an inner arc; $\alpha_{\mathrm{o}}=$ axial angle for an outer arc; $\mathrm{Th}=$ hinge thickness;

$\mathrm{T}_{1}=$ orthogonal thickness. An axial angle $(\alpha)$ and a thickness ratio $(\mathrm{R})$ for the fold are given by $\mathrm{R}=\mathrm{Th} / \mathrm{T} 1$ and $\alpha=\left(\alpha_{\mathrm{o}}+\alpha_{\mathrm{i}}\right) / 2$ respectively (Bhattacharya, 2005)

A fold is classified into four types based on this classification (Fig. 15).

\begin{tabular}{|c|c|c|c|}
\hline Fold Type & $\begin{array}{c}\text { Thickness Ratio } \\
\qquad \mathrm{R}=\mathrm{T}_{\mathrm{h}} / \mathrm{T}_{\mathrm{i}}\end{array}$ & $\begin{array}{l}\text { Axial Angles } \\
\left(\alpha_{0}-\text { outer arc }\right. \\
\left.\alpha_{i}-\text { inner arc }\right)\end{array}$ & Fold Profile \\
\hline $\begin{array}{l}\text { T - FOLD } \\
\text { (Thickened Fold) }\end{array}$ & $R>1$ & $\alpha_{0}<\alpha_{i}$ & \\
\hline $\begin{array}{l}\text { P - FOLD } \\
\text { (Parallel Fold) }\end{array}$ & $R=I$ & $\alpha_{0}=\alpha_{i}$ & \\
\hline $\begin{array}{l}\text { S - FOLD } \\
\text { (Supratenuous Fold) }\end{array}$ & $R<1$ & $\alpha_{0}>\alpha_{i}$ & \\
\hline $\begin{array}{l}\text { FLOWFOLD } \\
\text { (in genetic/mechanical } \\
\text { sense) }\end{array}$ & $\begin{array}{l}\text { Variable } \\
\text { Values }\end{array}$ & $\begin{array}{l}\text { Variable } \\
\text { Values }\end{array}$ & \\
\hline
\end{tabular}

Fig.15. Folds based on Axial Angle and Thickness Ratio Classification (Bhattacharya, 2005) 
The study used a cross-section (A - $\mathrm{A}^{-}$) (Fig. 10), Because it passes through crest maximum curvature, the axial angle $(\alpha)$ and the thickness ratio (R) of the Faihaa structure section were computed using the Rumaila Formation as the inner arc and the Mishrif Formation as the outer arc, as shown in Table 3.

Table 3. The classification of thickness and ratio of axial angle Faihaa Structure results

\begin{tabular}{|c|c|c|c|c|c|}
\hline $\begin{array}{c}\text { Axial Angle Outer } \\
\operatorname{Arc}\left(\alpha_{0}\right)\end{array}$ & $\begin{array}{c}\text { Axial Angle Inner Arc } \\
\qquad\left(\alpha_{i}\right)\end{array}$ & $\begin{array}{c}\text { Thickness } \\
\text { Hinge (Th) (m) }\end{array}$ & $\begin{array}{c}\text { Thickness } \\
\text { Limb (Tı) } \\
\text { (m) }\end{array}$ & $\mathbf{R}$ & $\boldsymbol{\alpha}$ \\
\hline $164.3^{\circ}$ & $167.4^{\circ}$ & 260 & 220 & 1.18 & 165.85 \\
\hline
\end{tabular}

According to the results, Faihaa structure is Thickened Fold.

\subsubsection{Dip of axial surface}

The Axial Surface is surface, which contains hinge lines from sequential folded surfaces. Based on the axial surface dip, folds are categorized into three types, as shown in Table 4.

Table 4. Classification of the folds based on the dip of Axial Surface (Van Der Pluijm and Marshak, 2004)

\begin{tabular}{lc}
\hline Type of Fold & Dip of axial surface \\
\hline Recumbent & $0^{\circ}-10^{\circ}$ \\
Inclined & $10^{\circ}-70^{\circ}$ \\
Upright & $70^{\circ}-90^{\circ}$ \\
\hline
\end{tabular}

According to the dip values of the axial surface in a table (2), the Faihaa Structure is upright fold

\subsubsection{Symmetry of fold}

Barnes and Lisle, 2004 used the relationship between the length of limbs to explain the symmetry. The limbs of Asymmetrical folds are generally of uneven dip and length. The cross-section $\left(\mathrm{A}-\mathrm{A}^{-}\right)$confirmed that Faihaa Structure is an asymmetrical fold due to a western limb is shorter than an eastern limb of fold (Fig. 9).

\subsection{Based on Fold Dimensions}

This categorization is based on folds length (L) to width (W) in relation to the same layer boundary (Fig. 16). There are three types (Jaroszewski, 1984):

- Basins and Domes fold $\mathrm{L} / \mathrm{W}<2$

- Brachy fold $5>\mathrm{L} / \mathrm{W}>2$

- Linear fold $\mathrm{L} / \mathrm{W}>5$

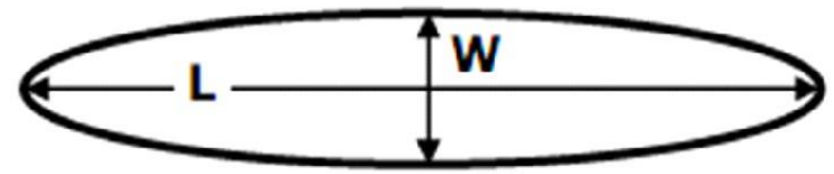

Fig.16. The folds Classification based on folds length (L) to width (W) ratio (Jaroszewski, 1984) 
The measuring of axial maximum width and length from contour maps of the Mishrif Formation map (contour no. 2800) and Ahmadi Formation map (contour no. 3150) (Figs. 5 and 6) (Table 5).

Table 5. The results of fold dimensions

\begin{tabular}{lcccc}
\hline Formation & Contour no. & $\begin{array}{c}\text { Length Axial } \\
(\mathbf{L})(\mathbf{m})\end{array}$ & $\begin{array}{c}\text { Width Axial } \\
(\mathbf{W})(\mathbf{m})\end{array}$ & Ratio (L / W) \\
\hline Mishrif & 2800 & 37400 & 8500 & 4.40 \\
Ahmadi & 3150 & 42300 & 9500 & 4.45 \\
\hline
\end{tabular}

Based on the Ratio (L/W) value for Mishrif and Ahmadi Formation, the Faihaa structure belongs to the Brachy fold. According to all the classifications, Faihaa Fold is anticline structure, gentle, thickened, asymmetrical, and brachy fold.

\section{Conclusions}

Structural contour maps and well logs data were used to analyze the structure of Faihaa Oil Field. The study revealed that the Faihaa Oil Field is an anticline structure. The average dip value of an axial surface is $89.7^{\circ}$, while the plunge of hinge line between $4^{\circ}-4.2^{\circ}$ referred to that Faihaa Oil Field is upright and gentle fold. Based on the thickness ratio and axial angle, the Faihaa Structure is a thickened fold. The eastern limb of the fold is longer than the western limb, so Faihaa Structure is an asymmetrical structure. The difference in dimensions $5<$ Length / Width $<2$ confirmed that the Faihaa structure is a brachy fold.

\section{Acknowledgements}

I would express my thank to Basrah Oil Company and Oil Exploration Company for providing data. The authors are very grateful to the Editor in Chief Prof. Dr. Salih M. Awadh, the secretary of Journal Mr. Samir R. Hijab, and the Technical Editors for their great efforts and valuable comments.

\section{References}

Alhassani, M., 2020. Biostratigraphy, and Depositional Environment of Yamama Formation in Faihaa Oil Field, Southern Iraq, M. Sc. Thesis, College of Science, University of Baghdad, Baghdad, Iraq, 85 pp.

Aqrawi, A. A., Goff, J. C., Horbury, D. \& Sadooni, F. 2010.The Petroleum Geology of Iraq, Scientific Press Ltd, 424 pp.

Altimimi, A., 2019. Advanced Reservoir Characterization tools and Modeling for carbonate reservoir Yamama Formation in Faihaa Oil Field in southern Iraq, Ph. D thesis, College of Science, University of Baghdad, Baghdad, Iraq, 139-142.

Barnes, J. W., Lisle, R. J. 2004. Basic Geological Mapping. 4th. Ed. Jone Whily Son Ltd. UK. 345 pp.

Bhattacharya, A. R. 2005. A classification of folds: role of axial angle and thickness ratio geoinformatics. India,16 (1), 27- 34.

Fleuty, N. J. 1964. The Description of Folds. Proceedings Geological Association, London, 75, 461-492.

Fossen, H., 2015. Structural Geology (Cambridge University Press).

Jaroszewski, W. 1984. Fault and Fold Tectonic, Ellis Horwood Ltd. England, 565 pp.

Jassim, S. Z, Goff, J. C., 2006. Geology of Iraq. Dolin, Prague and Moravian Museum, Brno (Czech Republic), $341 \mathrm{pp}$.

Kuwait Energy (K.E.I.L.), 2014. 2D and 3D seismic survey section, 12.

Park, R. G., 1997. Foundation of Structural Geology. The Alden Press, Osney Mead, Oxford, $3^{\text {rd }}$ edition. U.K.

S. O. C., 2016. Final Geological Report, Iraq.

Van Der Pluijm, B. A., Marshak, S. 2004. Earth Structure an Introduction to Structural Geology and Tectonic McGraw Hill, 673 pp. 